\title{
Pengaruh pewarna alami kulit buah naga merah (Hylocereus polyrhizus (F.A.C. Weber) Britton \& Rose) terhadap kadar total fenol dan vitamin $\mathrm{C}$ nata de coco
}

\author{
Inayah Rizkia Lailiati ${ }^{{ }^{*}}$, Novi Febrianti ${ }^{2}$ \\ Pendidikan Biologi, Fakultas Keguruan dan Ilmu Pendidikan, Universitas Ahmad Dahlan \\ Jl. Jendral Ahmad Yani (Ringroad Selatan) Tamanan, Banguntapan, Bantul \\ Daerah Istimewa Yogyakarta 55191 \\ 1 inayahrizkia97@gmail.com*; novifebrianti@pbio.ac.id \\ *korespondensi penulis
}

\begin{abstract}
Abstrak
Kulit buah naga merah belum dimanfaatkan secara optimal dan hanya dijadikan sebagai limbah. Padahal, kulit buah naga merah berpotensi sebagai pewarna alami karena mengandung zat warna betasianin, total fenol dan vitamin $\mathrm{C}$ tinggi yang dapat meningkatkan nilai gizi suatu produk makanan,seperti nata de coco. Penelitian ini bertujuan untuk mengetahui pengaruh pewarna alami kulit buah naga merah terhadap kadar total fenol dan vitamin $\mathrm{C}$ nata de coco. Penelitian ini merupakan penelitian eksperimen menggunakan RAL (Rancangan Acak Lengkap) yang terdiri dari 1 perlakuan yaitu penambahan filtrat kulit buah naga merah pada nata de coco dengan variasi konsentrasi $0 \%, 25 \%$, 50\% dan 100\%. Parameter yang diamati yaitu kadar total fenol dan vitamin $\mathrm{C}$ nata de coco. Data yang diperoleh dianalisis dengan SPSS 20.0 melalui uji ANOVA, dilanjutkan dengan uji LSD pada taraf 5\% untuk mengetahui perbedaan antar perlakuan. Hasil penelitian menunjukkan bahwa penambahan pewarna alami filtrat kulit buah naga merah konsentrasi $100 \%$ menghasilkan nata de coco dengan kadar total fenol dan vitamin $\mathrm{C}$ tertinggi masing-masing sebesar $0,0313 \pm 0,01006 \mathrm{mgGAE} / \mathrm{g}$ dan $157 \pm 0,63 \mathrm{mg} / 100 \mathrm{~g}$.
\end{abstract}

Kata kunci: Pewarna alami, Kulit buah naga merah, Fenol, Vitamin C, Nata de coco

\begin{abstract}
Red dragon fruit peel has not been used optimally and is only used as waste. Even though, red dragon fruit peel has high potential as a natural dyes because it contains betacyanin, total phenolyc content and vitamin $\mathrm{C}$ which can incerase nutrition of food products, such as nata de coco. The purpose of this study was to determine effect of natural dyes from red dragon fruit peel on total phenolic content and vitamin $\mathrm{C}$ nata de coco. The experimental design used was the single randomized design (SRD) with various concentration $(0 \%, 25 \%, 50 \%$ and $100 \%)$. The data analysis was done as ANOVA, if significance is detected, further data analysis is continued by LSD with confidence interval of $5 \%$. The results of this study showed that the addition of natural dyes from red dragon fruit peel at $100 \%$ concentration has the highest total phenolic content and vitamin $\mathrm{C}$ nata de coco, with the following characteristics : total phenolic content $0,0313 \pm 0,01006 \mathrm{mgGAE} / \mathrm{g}$ and vitamin C $157 \pm 0,63 \mathrm{mg} / 100 \mathrm{~g}$.
\end{abstract}

Keywords: Natural dyes, Red dragon fruit peel, Total phenolic content, Vitamin C, Nata de coco 


\section{PENDAHULUAN}

Indonesia merupakan negara tropis yang memiliki kekayaan hayati yang tinggi, salah satunya adalah buah naga merah. Pada umumnya buah naga merah dikonsumsi masyarakat luas sebagai penghilang dahaga yang nyatanya menghasilkan hasil samping berupa kulit buah. Menurut Saati (2010), kulit buah naga merah yang mempunyai berat 30-35\% dari berat buah selama ini pemanfaatannya belum optimal dan lebih sering dijadikan sebagai limbah.

Kulit buah naga merah nyatanya mengandung banyak zat, seperti fenol, vitamin $\mathrm{C}$ dan antioksidan yang lebih besar dibandingkan pada daging buahnya (Putri dkk., 2015). Kulit buah naga merah juga memiliki kandungan betasianin. Zat betasianin merupakan salah satu zat warna alami yang dapat dimanfaatkan sebagai alternatif pewarna sintetis pada bahan makanan seperti nata de coco karena memiliki warna yang menarik, mudah larut dalam air, dan mempunyai aktivitas antioksidan yang tinggi sehingga lebih aman untuk dikonsumsi bagi tubuh (Herbach dkk., 2006). Penambahan pewarna alami kulit buah naga merah pada nata de coco dapat juga digunakan sebagai alternatif untuk meningkatkan kualitas produk dan memperkaya nilai gizi karena kulit buah naga merah memiliki kandungan fenol dan vitamin $\mathrm{C}$ yang tinggi. Kandungan fenol dan vitamin $\mathrm{C}$ yang juga merupakan bagian dari antioksidan dapat bermanfaat untuk menangkal radikal bebas yang masuk ke dalam tubuh, sehingga dapat membantu sistem imun menjaga kekebalan tubuh (Sibagariang, 2010). Penelitian ini bertujuan untuk mengetahui pengaruh pewarna alami kulit buah naga merah (Hylocereus polyrhizus) terhadap kadar total fenol dan vitamin $\mathrm{C}$ nata de coco.

\section{METODE}

Penelitian ini merupakan penelitian eksperimen menggunakan RAL (Rancangan Acak Lengkap) yang terdiri dari 1 perlakuan yaitu penambahan filtrat kulit buah naga merah pada nata de coco dengan variasi konsentrasi $0 \%, 25 \%$, 50\% dan 100\%. Parameter yang diamati yaitu kadar total fenol dan vitamin $\mathrm{C}$ nata de coco. Penelitian diawali dengan identifikasi tanaman, pembuatan filtrat kulit buah naga merah, pembuatan nata de coco, aplikasi filtrat kulit buah naga merah pada nata de coco dan dilanjutkan dengan uji kadar total fenol dan vitamin C. Uji kadar total fenol menggunakan metode folin-ciocalteu, sedangkan uji vitamin C menggunakan metode iodimetri. Data yang diperoleh dianalisis dengan SPSS 20.0 melalui uji ANOVA, dilanjutkan dengan uji LSD pada taraf 5\% untuk mengetahui perbedaan antar perlakuan. 


\section{HASIL DAN PEMBAHASAN}

\section{Kadar Total Fenol}

Penetapan kadar total fenol diperoleh melalui metode folin-ciocalteu. Metode ini menggunakan spektrofotometer UV-Vis untuk melihat perubahan warna yang terjadi saat larutan pereaksi dicampurkan dengan larutan standar. Penetapan kadar total fenol didahului dengan penetapan waktu operasional, pengukuran panjang gelombang maksimum, pembuatan kurva baku larutan standar asam galat dan pengukuran absorbansi larutan. Kurva baku larutan standar asam galat dibuat dengan 6 variasi konsentrasi, yaitu 0;0,50;0,1;0,15; 0,2 dan 0,25 $\mathrm{mg} / \mathrm{mL}$. Pembuatan kurva larutan standar asam galat dilakukan untuk mengetahui hubungan antara konsentrasi dengan absorbansi. Hasil pengukuran absorbansi dapat dilihat pada Tabel 1.

\begin{tabular}{ccc}
$\frac{\text { Tabel 1. Absorbansi larutan standar asam galat }}{3 \text { No }}$ & $\begin{array}{c}\text { Konsentrasi } \\
\text { (mg/mL) }\end{array}$ & Absorbansi \\
\hline 1 & 0 & 0 \\
2 & 0,05 & 0,0466 \\
3 & 0,1 & 0,0932 \\
4 & 0,15 & 0,1398 \\
5 & 0,2 & 0,1864 \\
6 & 0,25 & 0,233 \\
\hline
\end{tabular}

Berdasarkan Tabel 1, dapat dibuat hubungan antara konsentrasi larutan standar asam galat dengan absorbansi, sehingga diperoleh persamaan regresi liniernya $y=3,250 x+$ 0,0179, dengan konsentrasi korelasi $\mathrm{R}^{2}$ sebesar 0,9981. Kadar total fenol dalam sampel selanjutnya dihitung dengan mensubtitusikan nilai absorbansi larutan standar kedalam variabel y pada persamaan regresi. Hasil kadar total fenol dapat dilihat pada Gambar 1.

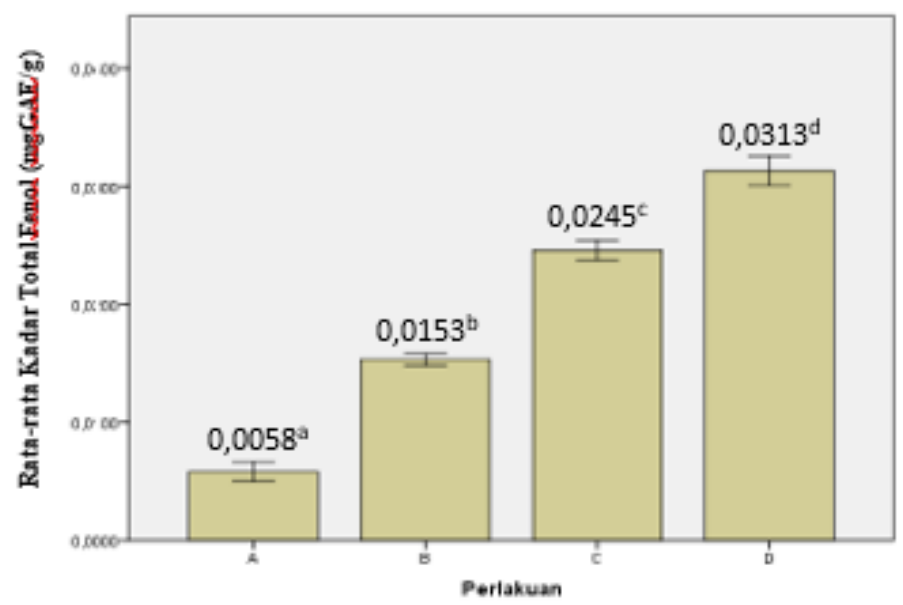

Gambar 1. Diagram perbandingan kadar fenol nata de coco 
Keterangan :

$\mathrm{A}=$ Kontrol (Konsentrasi 0\%) $; \mathrm{B}=$ Konsentrasi 25\% ; $\mathrm{C}=$ Konsentrasi $50 \%$; $=$ Konsentrasi $100 \%$

Berdasarkan hasil yang diperoleh menunjukkan bahwa semakin tinggi konsentrasi kulit buah naga merah yang digunakan maka semakin tinggi pula kadar total fenol nata de coco. Kadar total fenol yang diperoleh dalam penelitian ini sangat rendah jika dibandingkan dengan penelitian mengenai kulit buah naga merah yang dilakukan oleh Nurliyana dkk. (2010) yang menyatakan bahwa kandungan total fenol dalam kulit buah naga merah yaitu sebesar 1049,18 mgGAE/100g. Hal ini dapat disebabkan perbedaan metode yang digunakan, Nurliyana dkk., menggunakan metode ekstraksi, sedangkan dalam penelitian ini kulit buah naga merah dihaluskan dengan blender sehingga dihasilkan filtrat kulit buah naga merah. Menurut Oktavia (2011), metode ekstraksi dapat mengisolasi senyawa aktif dari bahan alam, seperti senyawa fenol sehingga kandungan zat aktif yang diinginkan lebih tinggi dibandingkan metode lain. Penggunaan filtrat kulit buah naga merah dalam penelitian ini dikarenakan filtrat lebih mudah diterapkan dalam kehidupan sehari-hari dan lebih cocok untuk digunakan sebagai bahan pewarna pada makanan.

\section{Kadar Vitamin C}

Kadar vitamin C (asam askorbat) diperoleh melalui metode iodimetri dengan titrasi menggunakan iodium sebanyak 3 kali pengulangan. Indikator yang digunakan dalam titrasi iodium adalah indikator amilum $1 \%$. Hasil perhitungan kadar vitamin $\mathrm{C}$ dapat dilihat pada Tabel 2.

Tabel 2. Kadar vitamin C nata de coco

\begin{tabular}{cccccc}
\hline \multirow{2}{*}{ No } & \multirow{2}{*}{ Perlakuan } & \multicolumn{2}{c}{ Pengulangan $\mathbf{( m g / 1 0 0 g )}$} & Rata-rata \\
\cline { 3 - 5 } & & I & II & III & (mg/100g) \\
\hline 1 & A & 32,16 & 31,47 & 32,48 & $32,03 \pm 0,51$ \\
2 & B & 60,23 & 61,43 & 59,78 & $60,48 \pm 0,85$ \\
3 & C & 86,84 & 85,70 & 84,80 & $85,78 \pm 1,02$ \\
4 & D & 157,44 & 157,29 & 156,27 & $157 \pm 0,63$ \\
\hline
\end{tabular}

Berdasarkan Tabel 2 maka dapat dibuat diagram perbandingan kadar vitamin $\mathrm{C}$ nata de coco yang dapat dilihat pada Gambar 2. 


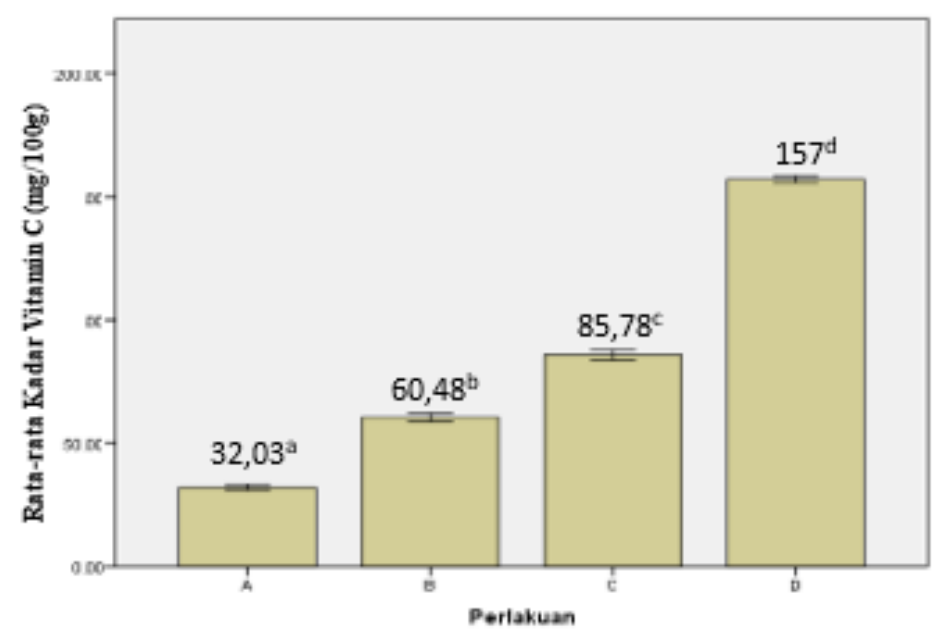

Gambar 2. Diagram perbandingan kadar vitamin C nata de coco

Keterangan :

$\mathrm{A}=$ Kontrol (Konsentrasi 0\%) $; \mathrm{B}=$ Konsentrasi 25\% ; $\mathrm{C}=$ Konsentrasi $50 \%$; $=$ Konsentrasi $100 \%$

Berdasarkan Gambar 2 menunjukkan bahwa semakin tinggi konsentrasi kulit buah naga merah yang digunakan maka semakin tinggi pula kadar vitamin $\mathrm{C}$ nata de coco. Nata de coco perlakuan B merupakan produk yang paling tepat untuk dikonsumsi karena paling mendekati Angka Kecukupan Gizi (AKG) vitamin C bagi tubuh orang dewasa. Menurut Putra (2011), Angka Kecukupan Gizi (AKG) vitamin C bagi orang dewasa yakni sekitar $60 \mathrm{mg}$ per hari, namun karena banyaknya radikal bebas seperti polusi di lingkungan (asap kendaraan bermotor dan asap rokok) maka penggunaan vitamin $\mathrm{C}$ sebagai antioksidan perlu ditingkatkan hingga dua kali lipatnya yaitu sekitar 120 mg. Berdasarkan hal tersebut, tingginya kandungan vitamin $\mathrm{C}$ nata de coco perlakuan $\mathrm{C}$ dianggap tidak berlebihan, karena masih dalam batas Angka Kecukupan Gizi vitamin C. Menurut Rauf (2015), konsumsi vitamin $\mathrm{C}$ berlebihan akan menimbulkan masalah pencernaan, gangguan pada ginjal, bahkan gangguan yang berhubungan dengan kerusakan jaringan otak.

\section{SIMPULAN}

Penambahan pewarna alami filtrat kulit buah naga merah konsentrasi $100 \%$ menghasilkan nata de coco dengan kadar total fenol dan vitamin $\mathrm{C}$ tertinggi masing-masing sebesar 0,0313 $\pm 0,01006 \mathrm{mgGAE} / \mathrm{g}$ dan $157 \pm 0,63 \mathrm{mg} / 100 \mathrm{~g}$. 


\section{REFERENSI}

Herbach, K.M., Stintzing, F.C., and Carle, R. 2006. Betalain Stability and Degradation Structural and Chromatic Aspects. Journal of Food Science. 71(4) : 301 - 307.

Nurliyana, R., Z.I. Syrd, S.K., Mustapha, M.R., Aisyah, R.K., \& Kamarul. 2010. Antioxidant Study of Pulps and Peels of Dragon Fruits : A Comparative Study. International Food Research Journal. 17 : 367-375.

Oktavia, J.D. 2011. Pengoptimuman Ekstraksi Flavonoid Daun Salam (Syzygium polyanthum) dan Analisis Sidik Jari dengan Kromatografi Lapis Tipis. Skripsi. Bogor: Fakultas Matematika dan Ilmu Pengetahuan Alam Institut Pertanian Bogor.

Putra, Azhar. 2011. Penetapan Kadar Vitamin C dari Bawang Putih (Allium sativum L.) Secara Titrasi 2,6-diklorofenol Idofenol. Skripsi. Medan : Universitas Sumatera Utara.

Rauf, Rusdin. 2015. Kimia Pangan. Yogyakarta : Andi.

Putri, Ni Ketut, I Wayan, G.G., dan I Wayan Suwarsa. 2015.Aktivitas Antioksidan Antosianin dalam Ekstrak Etanol Kulit Buah Naga Super Merah (Hylocereus Costaricensis) dan Analisis Kadar Totalnya. Jurnal Kimia. 9(2) : 243-251.

Saati, E. A. 2010. Identifikasi dan Uji Kualitas Pigmen Kulit Buah Naga Merah (Hylocareus costaricensis) Pada Beberapa Umur Simpan dengan Perbedaan Jenis Pelarut. GAMMA. 6 (1): 25 - 34.

Sibagariang, Eva Ellya. 2010. Gizi dalam Kesehatan Reproduksi. Jakarta: Trans Info Media. 